
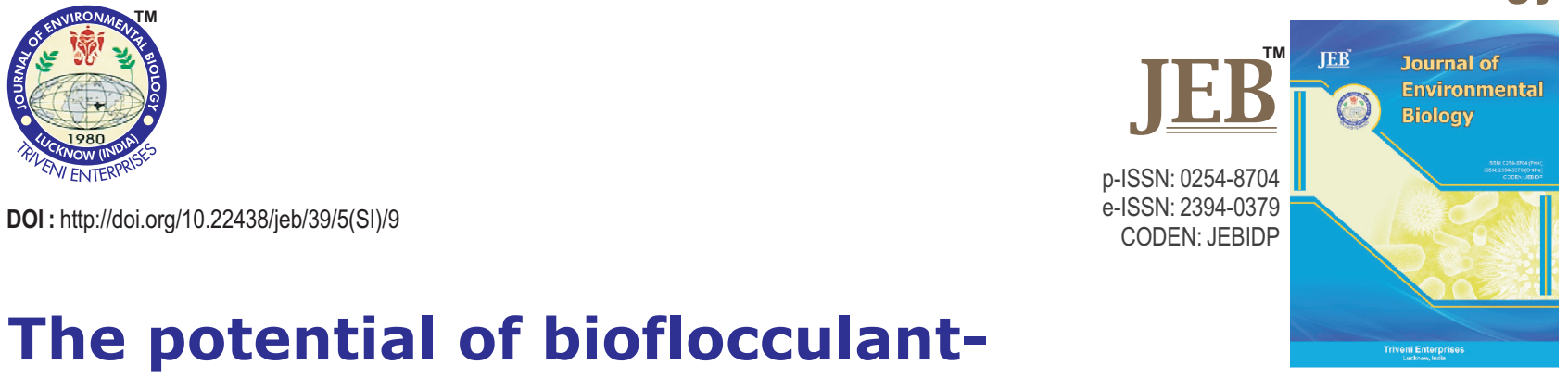

\title{
The potential of bioflocculant- producing bacteria as inoculum for biofloc based systems
}

\section{Authors Info}

A.A.C. Harun', N.A. Ghazali', N.F.C. Hashim 1 , N.A.H. Mohammad', Mhd. Ikhwanuddin ${ }^{1,2}$, N. Ismail ${ }^{3}$, Z. lbrahim ${ }^{4}$ and N.A. Kasan ${ }^{1,2 *}$

1 Institute of Tropical Aquaculture, Universiti Malaysia Terengganu, 21030 Kuala Terengganu, Terengganu, Malaysia

${ }^{2} S c h o o l$ of Fisheries and Aquaculture Sciences, Universiti Malaysia Terengganu, 21030 Kuala Terengganu, Terengganu, Malaysia

${ }^{3}$ Institute of Marine Biotechnology, Universiti Malaysia Terengganu, 21030 Kuala Terengganu, Terengganu, Malaysia

${ }^{4}$ Department of Biological Science, Faculty of Bioscience and Bioengineering, Universiti Teknologi Malaysia, 81300, Skudai, Johor, Malaysia

${ }^{*}$ Corresponding Author Email : norazman@umt.edu.m

Key words

Bioflocculant-producing bacteria Extracellular polymeric substance Flocculation activity Priological flocculants

Publication Info

Paper received : 25.07 .2017 Revised received : 20.08.2017 Re-revised received : 25.09 .207 Accepted : 28.12.2017

\begin{abstract}
Aim: Biological flocculants has been widely used around the world to replace the usage of synthetic flocculants for wastewater treatment. A new green technology using biological flocculant known as biofloc system was developed which offers zero water exchanged, low feed conversion ratio (FCR) and high nutritional profile. This study was conducted to determine the most potential bioflocculant-producing bacteria isolated from biofloc sample in Pacific Whiteleg shrimp, P. vannamei culture pond.

Methodology: Biofloc sample was collected using Imhoff cone and bacteria was isolated. The most abundant bacteria isolated throughout $P$. vannamei culture period was selected for screening of bioflocculant-producing bacteria using YPG medium and flocculation activity using floc-jar test.
\end{abstract}

Results: Screening of bioflocculant-producing bacteria showed that B. infantis, N. aquimarinus, $B$. cereus, $H$. venusta, Pseudoalteromonas sp., and $B$. safensis were characterized as highly mucoid and ropy colony morpologies. The highest flocculation activity with $93 \%$ was showed by $B$. infantis followed by $N$. aquimarinus $(91 \%)$, B. cereus (87\%), H. venusta $(79 \%)$, Pseudoalteromonas $(78 \%)$, while the lowest flocculation activity was showed by $B$. safensis with $69 \%$.

Interpretation: As bacteria grew, extracellular polymeric substances (EPS) produced were involved in flocculation process. Each bacteria produced different EPS composition which differed their ability in flocculation process. Therefore, bacteria with high flocculation activity are potentially used as inoculum to increase flocculation process in biofloc production.

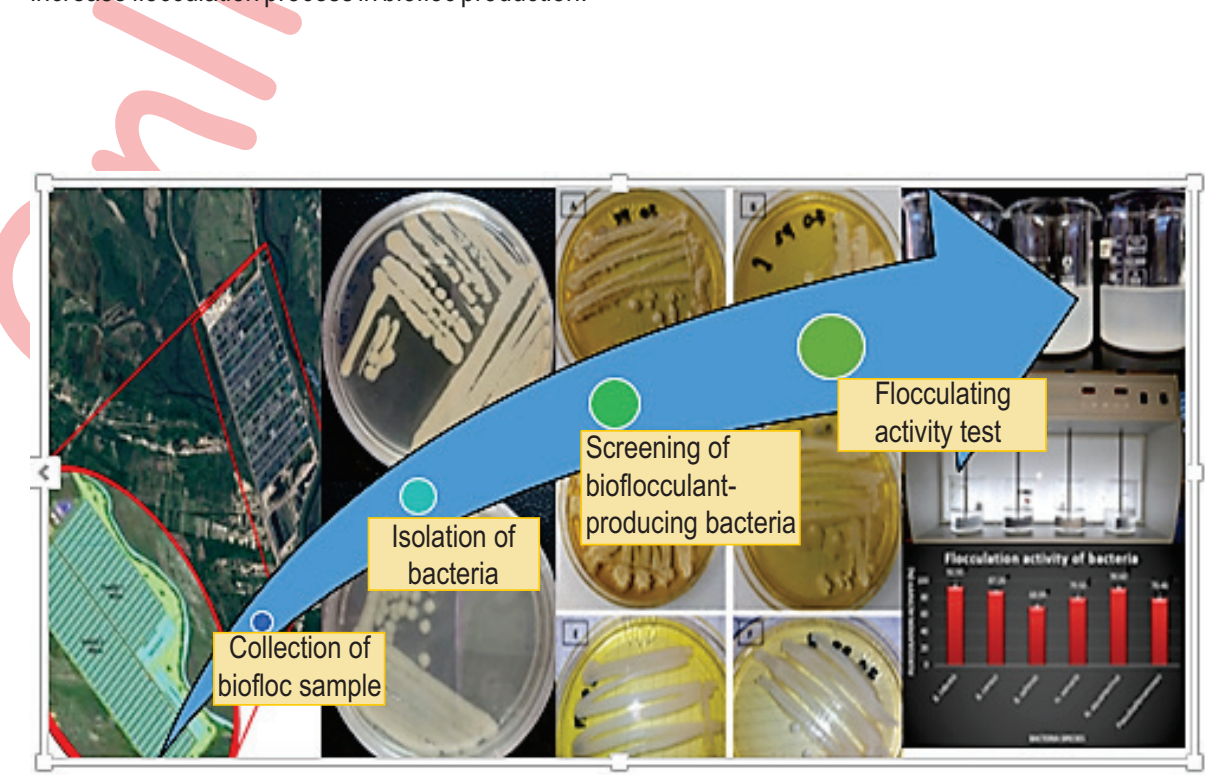




\section{Introduction}

Recently, aquaculture have expand rapidly to overcome dependable on fisheries resources and provide more than $50 \%$ of total fisheries production (FAO, 2010) with the expansion of aquaculture sector, issues on water quality management has also rised since aquaculture effluent can be high in dissolved nitrogen (Avnimelech, 2012). To overcome the problem, new and green technology of culturing technique using microorganisms are widely used such as Zero Exchanged Autotrophic Haterotrophic System (ZEAH) (Burford et al., 2003; Burford et al., 2004), microbial floc system (Avnimelech, 2007; Ballester et al., 2010), single-cell protein production system (Avnimelech, 1989), suspended-growth system (Hargreaves, 2006) and active sludge system (Rakocy et al., 2004). Alternatively, biofloc technology (BFT) was first developed by Yoram Avnimelech in 1989 with the concept of bioreactor for single cell protein production (Avnimelech, 1989; Avnimelech, 2012).

The major concept of BFT is the addition of carbon that increase heterotrophic bacterial growth that causes aggregations of flocs, called bioflocs. Bioflocs are made up of algae, fungi, bacteria, diatom, protozoa, faeces, and uneaten feed that are held together in a loose matrix of mucus secreted by bacteria during their growth and bound by filamentous microorganisms or electrostatic attraction (Hargreaves, 2013). During the flocculation process, there are several steps that occur due to the electrostatic attraction of suspended particles, filamentous microorganisms, and loose matrix of mucus or extracellular polymeric substance (EPS) secreted by bacteria during their growth (Hargreaves, 2013). Commonly, fine particles of uneaten feed, faecal, and sludge are freely suspended in the water column and only settle down when flocculation occurrs (Crab et al., 2012). The surface of most suspended particles in water have a negative charge and particles of the same charge will repel each other (Chui et al., 2014). This action cause suspended particles to remain suspended in the water column. The use of coagulant assists in the flocculation process by electrostatic attraction. Coagulants have been used to stabilize the charge and allow clumping of suspended particles to form floc (Prakash et al., 2014). Filamentous microorganisms are also involved in formation of biofloc where cilia from these microorganisms entrap suspended solids, as well as other substances. Attachments of filamentous microorganisms and other microorganisms on uneaten feed, fecal and sludge also promote the flocculation process (Crab, 2010; Dauda et al., 2018).

Despite electrostatic attractions and filamentous microorganisms, a loose matrix of mucus or EPS are one of the most important intermediaries in biofloc formation. EPS have been shown to be more efficient in the flocculation process due to adsorption of surface charge being reduced by bioflocculants and thus, attracting particles to floc sufficiently as attractive forces become more effective (Li et al., 2009). Bioflocculants are metabolites that are produced by bacteria during their growth. These metabolites are composed of polymerase substances such as extracellular polysaccharides, glycoproteins, functional proteins, nucleic acids and cellulose. These metabolites function as mucus or substrates in the aggregation of bioflocs (Gao et al., 2006).

Naturally, bioflocs begins to develop after 30 days, with tformation of a green color due to the dominance of microalgae (Lara et al., 2016). Afterwards, there is a transition process once the algae are hindered from sunlight. When the algae begins to crash, bacteria grow forming a brown bioflocs that are dominated by bacteria (Hargreaves, 2013). Brown bioflocs are more effective as compared to green bioflocs because bacteria are easier to control (Choo et al., 2015). In addition, bacterial flocs are involved in nitrification of nitrogen, form microbial protein, and may act as probiotics to the cultured organisms (Simon, 2005).

The use of BFT offers many benefits to water quality as well as to the aquaculture organisms, such as growth or disease resistance (Xu and Pan, 2013; Dauda et al., 2018). Therefore, bioflocs should be formed as early as possible although lag period can be up to 30 days. This can be reduced by introducing of bacterial innoculants as starter culture to promote biofloc formation. This study was conducted to understand the potential of bioflocculant-producing bacteria as inoculum to boost biofloc formation.

\section{Materials and Methods}

Collection of biofloc samples : Bacteria were isolated from biofloc in a white-leg Litopenaeus vannamei farm located in Setiu District, Terengganu, Malaysia which were operated by the Integrated Shrimp Aquaculture Park (iSHARP), Blue Archipelago Sdn. Bhd (Fig. 1). Bioflocs were collected from three selected shrimp's pond at iSHARP, Setiu, Terengganu following standard operating procedures by Blue Archipelago Sdn. Bhd. Three replicates consisted of two litres of water containing bioflocs, which were placed in an Imhoff cone overnight to settle the biofloc samples (Hargreaves, 2013). Sediment-like biofloc was further concentrated by centrifugation for $3 \mathrm{~min}$ at $6000 \mathrm{rpm}$ (Vijayalakshmi and Raichur, 2002). The concentrated biofloc sample was used to identify pure cultures of bacteria and any associated flocculation activity.

Isolation of bacteria from bioflocs : Marine agar was used as cultivation medium for isolation of all bacterial colonies in the biofloc pellet (Zaki et al., 2011). Biofloc pellets were then streaked onto marine agar and incubated for $24 \mathrm{hr}$ at $30^{\circ} \mathrm{C}$. After $24 \mathrm{hr}$, bacterial colonies on the incubation plate were sub-cultured in a zig-zag line. Then series of re-platings were conducted on isolated bacterial cultures until pure bacterial cultures were 


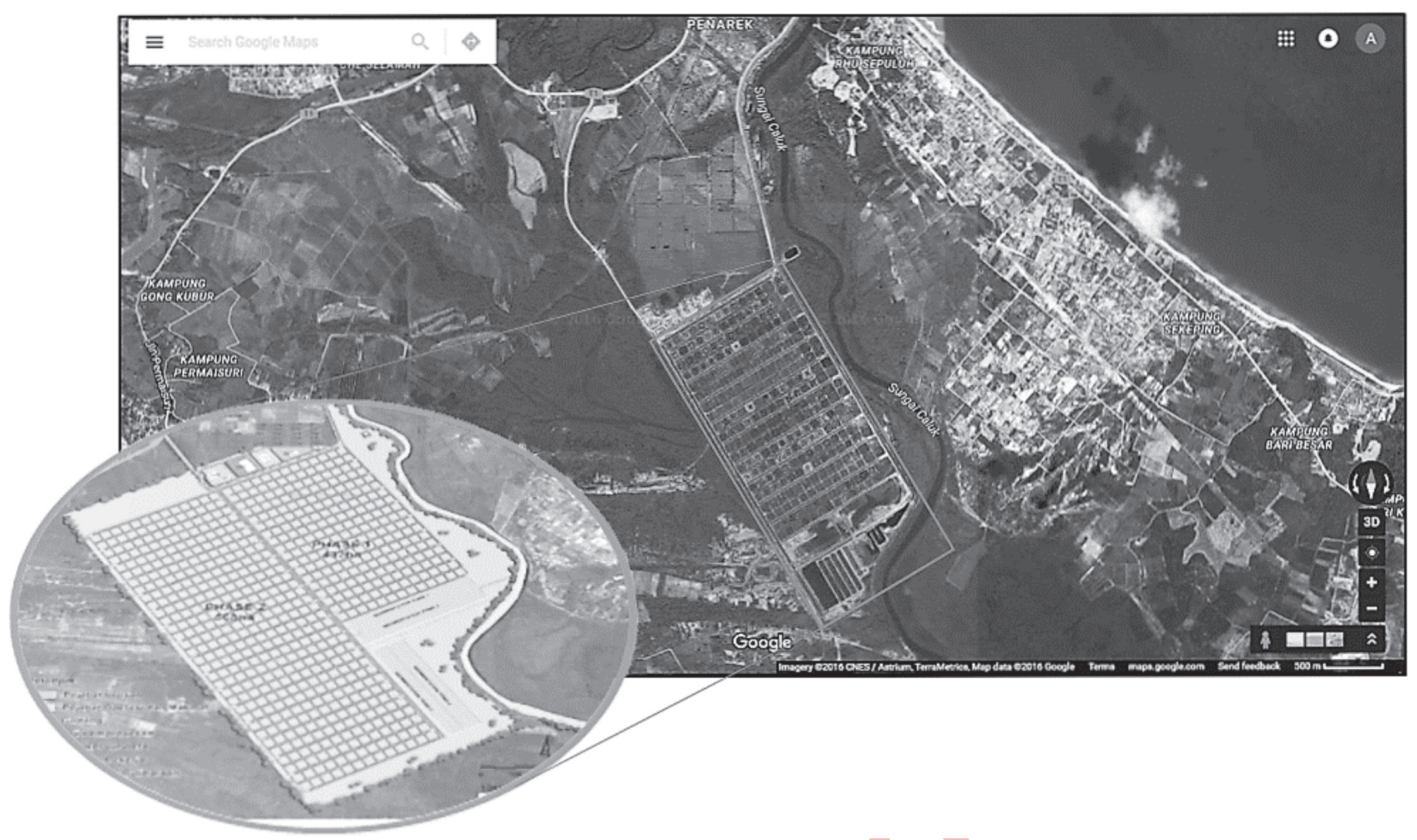

Fig. 1 : Location of the Pacific Whiteleg shrimp, P. vannamei culture ponds operated by Integrated Shrimp Aquaculture Park (iSHARP), Blue Archipelago Sdn. Bhd. at Setiu District, Terengganu, Malaysia

obtained. Isolated pure culture of bacteria were maintained on marine agar slants and kept in refrigerator at $4^{\circ} \mathrm{C}$ as a stock culture.

Screening of bioflocculant-producing bacteria : Screening of bioflocculant-producing bacteria were carried out following the method of Abd-El-Haleem et al. (2008). The pure isolates of bacteria were transferred into a Yeast Peptone Glucose (YPG) medium, which contained $10.0 \mathrm{~g}$ of glucose, $2.0 \mathrm{~g}$ of peptone, 0.5 $\mathrm{g}$ of urea, $0.5 \mathrm{~g}$ of yeast extract, $0.1 \mathrm{~g}$ of $\mathrm{NaCl}, 0.2 \mathrm{~g}$ of $\mathrm{MgSO}_{4} .7 \mathrm{H}_{2} \mathrm{O}, 0.2 \mathrm{~g}$ of $\mathrm{KH}_{2} \mathrm{PO}_{4}, 5.0 \mathrm{~g}$ of $\mathrm{K}_{2} \mathrm{HPO}_{4}$ and $15.0 \mathrm{~g}$ of bacteriological agar in one litre of deionized water at $\mathrm{pH} 7.0 \mathrm{using}$ 1.0 M sodium hydroxide and $1.0 \mathrm{M}$ hydrochloric acid and incubated at $35^{\circ} \mathrm{C}$ for $48 \mathrm{hr}$ (Chen and Zhao, 2003; Zaki et al., 2011). Isolated strains with highly mucoid and ropy colony morphologies in YPG medium were selected (Abd-El-Haleem et al., 2008).

Enrichment medium: Screened bacteria were grown in an enrichment medium, which was prepared as seeding medium by mixing $10.0 \mathrm{~g}$ of glucose, $0.5 \mathrm{~g}$ of urea, $0.2 \mathrm{~g}$ of $\mathrm{MgSO}_{4} .7 \mathrm{H}_{2} \mathrm{O}, 5.0 \mathrm{~g}$ of $\mathrm{K}_{2} \mathrm{HPO}_{4}, 2.0 \mathrm{~g}$ of peptone, $0.2 \mathrm{~g}$ of $\mathrm{KH}_{2} \mathrm{PO}_{4}$ and $0.5 \mathrm{~g}$ of yeast extract in one litre of filtered seawater at $\mathrm{pH} 7.0$ using $1.0 \mathrm{M}$ sodium hydroxide and $1.0 \mathrm{M}$ hydrochloric acid. This was incubated at $35^{\circ} \mathrm{C}$ for $48 \mathrm{hr}$ using an incubator shaker at $120 \mathrm{rpm}$ and $35^{\circ} \mathrm{C}$ for 3 days (Zhang et al., 2012 modified by Cosa et al.,
2011). The resultant culture broth was centrifuged at $8,000 \mathrm{rpm}$ for $15 \mathrm{~min}$ and the cell-free supernatant was used for assessing flocculation activity.

Flocculating activity assay: Flocculating activity was measured using a modified kaolin clay suspension method (Kurane et al., 1994). A concentration of a $5.0 \mathrm{~g} \mathrm{I}^{-1}$ kaolin clay suspension was prepared where $5.0 \mathrm{~g}$ of kaolin clay powder was suspended in one litre of deionized water. The kaolin clay suspension was adjusted to $\mathrm{pH} 7.0$ using $1.0 \mathrm{M}$ sodium hydroxide and $1.0 \mathrm{M}$ hydrochloric acid.

For the flocculating activity, $240 \mathrm{ml}$ of kaolin clay suspension and $10 \mathrm{ml}$ of bioflocculant solution (cell-free supernatant) were added into a $250 \mathrm{ml}$ beaker. The flocculating activity assay was started with rapid mixing at $230 \mathrm{rpm}$ for two min, followed by slow mixing for 1 min at a speed of $80 \mathrm{rpm}$ using a JLT4 Jar/Leaching Tester Velp Scientifica. The stirring speed was reduced to $20 \mathrm{rpm}$ and stirring was continued for $30 \mathrm{~min}$. The stirring apparatus was stopped and the samples in the beakers were allowed to settle for $30 \mathrm{~min}$.

The optical density (OD) of the clarifying solution at $3 \mathrm{~cm}$ below the surface was measured with a Shimadzu UV Spectrophotometer UV-1800 at $550 \mathrm{~nm}$. A control flocculating activity assay was prepared using similar method, where the bioflocculant solution was replaced with deionized water. The 
flocculating activity was calculated according to the following equation:

$$
\text { Flocculation activity }(\%)=[(B-A) / B] \times 100
$$

Where, A: absorbance reading of sample at $550 \mathrm{~nm}$; B: absorbance reading of control at $550 \mathrm{~nm}$

Statistical analysis: Flocculation activity of each bacterial sample was analysed using a one way-ANOVA, after prior confirmation of data homogeneity and normality. Significant differences between samples were determined at 0.05 level of probability. Statistical analyses were conducted using SPSS (2009) computer package.

\section{Results and Discussion}

Screening of bioflocculant-producing bacteria : From the bacterial sample collection obtained from biofloc in $L$. vannamei farm, six species showed positive flocculating activity. Six species of bioflocculant-producing bacteria showed a highly mucoid, cream colored, smooth, viscous, round, convex edge and ropy colony (Fig. 2) which indicated the production of bioflocculant substances during their growth when cultivated on YPG medium (Abd-El-Haleem et al., 2008; Kasan et al., 2015). All six species were identified as Bacillus infantis, B. cereus, B. safensis, Halomonas venusta, Nitratireductor aquamarinus and Pseudoalteromonas.

Flocculation activity : Flocculation activity ranged between $68 \%$ and $93 \%$ (Fig. 3), with the highest activity coming from $B$. infantis.

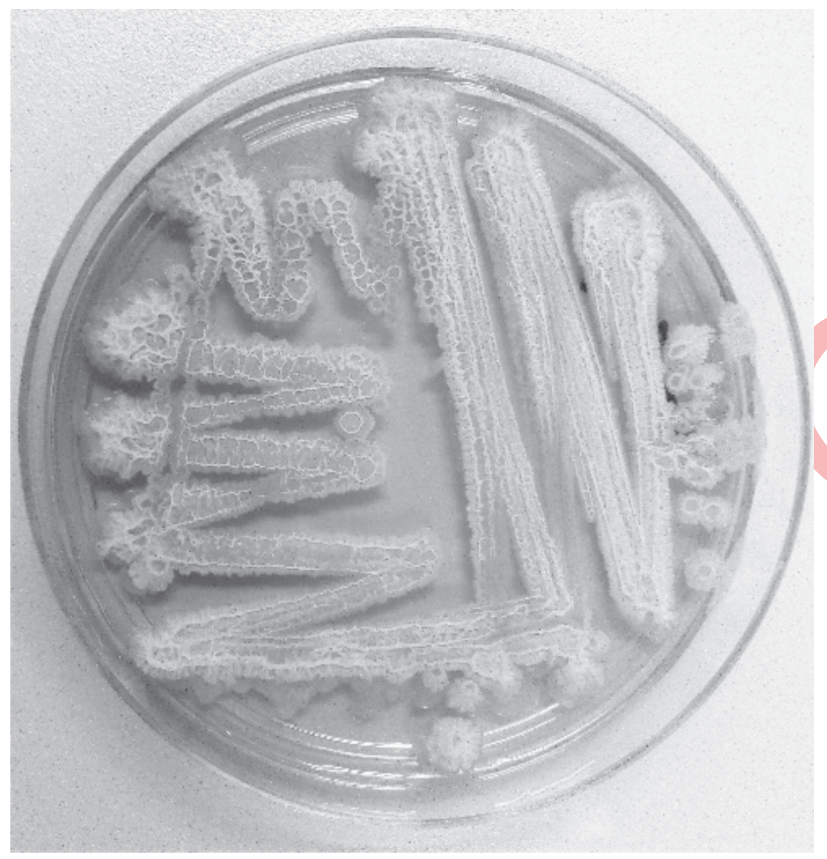

Fig. 2 : Bioflocculant-producing bacteria with highly mucoid and ropy colony
Flocculation process usually occurs in two ways, either by adhesion of ions or by adsorption of substances onto the mucus or EPS produced by bacteria (Brostow et al., 2009). The highest flocculation acivity in $B$. infantis indicates a higher production or best type of EPS in order for the kaolin clay to be floced into suspended material in the floc jar test method. Indeed, most bacteria produce different types of EPS during their growth (Mikutta et al., 2011). In this study, flocculation might have occured during the process by minerals being adsorped onto the clay by EPS substances secreted by the bacteria. This is because EPS was centrifuged from the cultured bacteria and then used in the floc jar test. Even though $B$. infantis produced the highest flocculation activity, other Bacillus species, that included $B$. cereus and B. safensis produced the flocculation activity of $87 \%$ and $69 \%$, respectively, among the tested bacteria.

Even among Bacillus species, they are producing different EPS such as $B$. subtilis producing polysacchariddes, $B$. consortium producing glycoprotein, B. safensis producing functional proteins and some other Bacillus species producing various EPS (Wu and Ye, 2007; Wang et al., 1995). Although B. infantis showed the highest flocculation activity, $N$. aquamarinus showed the second highest flocculation activity, that was almost as high as $B$. infantis at $91 \%(p<0.05)$. This is possibly due to the potential of $N$. aquamarinus secreting EPS that are suitable to flocculate koalin clay. N. aquamarinus has been described as a nitrifying or nitrate-reducing bacteria (Labbé et al., 2003). There is a lack of study on the application of $N$. aquamarinus as a potential probiotic, especially in aquaculture field, especially compared to Bacillus sp., that are well known to act as probiotic agents for cultured organisms (Touraki et al., 2012; Ng et al., 2014; Liu et al., 2015). In addition to flocculation activity, Bacillus sp. can potentially offer another benefits such as nitrogen cycling in the cultured pond (Sorokulova, 2013; Yang et al., 2011). However, N. aqumarinus are reportedly more effective at recycling nitrogen waste (Jang et al., 2011) and therefore the implications of using $N$. aquamarinus should be explored.

The second and third lowest flocculation activity was produced by $\mathrm{H}$. venusta $(80 \%)$ and Pseudoalteromonas sp. $(79 \%)$. H. venusta produce polysaccharides as their main EPS (Kumar et al., 2004) and is a polymer that has a low charged density (Sam et al., 2011), thus their ability to floc might only be enhanced in suspensions with high ionic strength. Li et al. (2008) showed that $P$ seudoalteromonas sp. were able to floc a variety of suspended solids such as kaolin clay, activated carbon, soil, magnesium oxide and aluminium oxide. Their ability to floc these materials may be enhanced in environments of high salinity and low water temperatures (Li et al., 2008).

Screening of bioflocculant-producing bacteria and flocculation activity using isolated bacteria from biofloc samples were successfully conducted. There were six species of bioflocculant-producing bacteria that showed more than $60 \%$ of 
Flocculation activity of bacteria

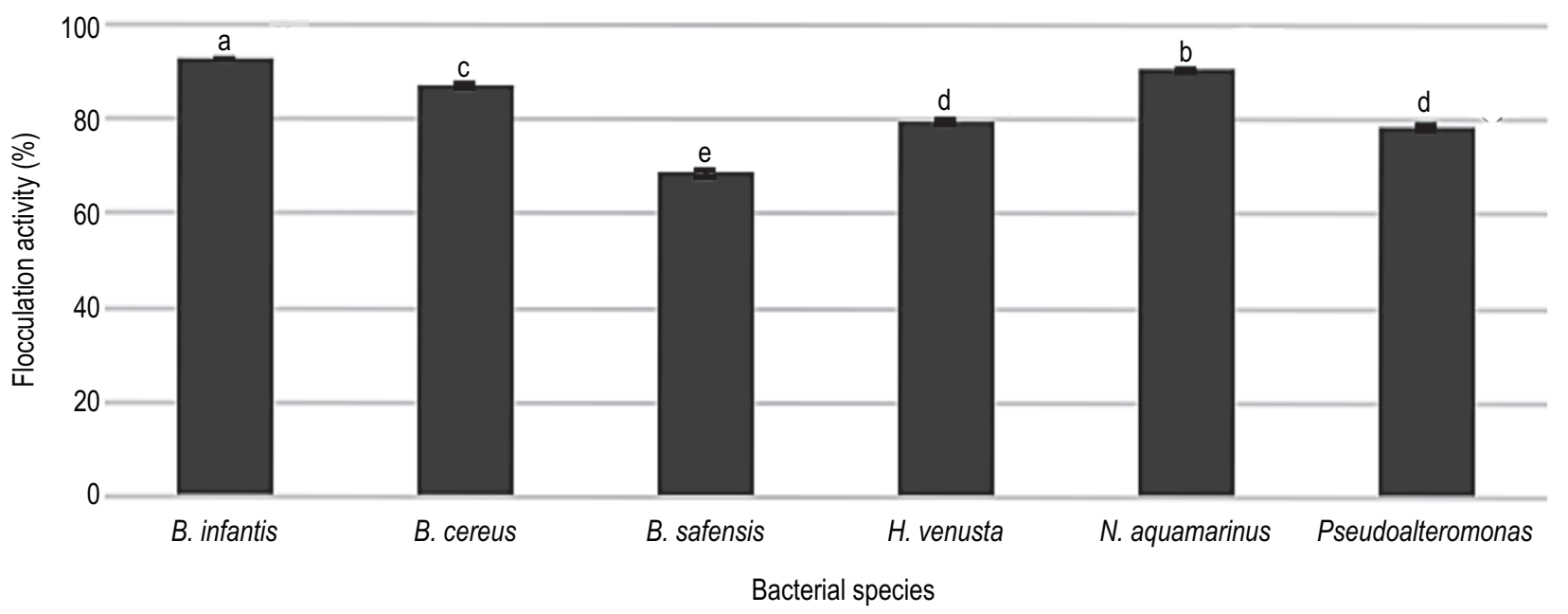

Fig. 3 : Flocculating activity of bioflocculant-producing bacteria consists of $B$. infantis, $B$. cereus, $B$. safensis, $H$. venusta, $N$. aquamarinus and Pseudoalteromonas sp. using floc jar test method

flocculation activity and were species specific that could be related to the type of EPS produced. The highest flocculation activity was found in B. infantis, which could be used to potentially reduce the start-up period for biofloc formation and potentially acting as a probiotic. It is suggested that futher studies characterize the EPS produced by bioflocculant-producing bacteria to better understand the efficiency of biofloc formation.

\section{Acknowledgments}

Authors would like to thank the Ministry of Education, Malaysia (MOE) for financial support under Fundamental Research Grant Scheme, FRGS (Vot no. 59401). We would also like to acknowledge iSHARP, Blue Archipelago Berhad at Setiu, Terengganu, Malaysia for aquaculture facilities of $P$. vannamei culture ponds, and also to all the hatchery officers and staffs at Institute of Tropical Aquaculture, Universiti Malaysia Terengganu for their assistance and guidance throughout the research period.

\section{References}

Abd-El-Haleem, D.A.M., R.F. Al-Thani, T. Al-Mokemy, S. Al-Marii and F. Hassan: Isolation and characterization of extracellular bioflocculants produced bacteria isolated from Qatari ecosystems. Pol. J. Microbiol., 57, 231-239 (2008).

Avnimelech, Y.: Feeding with microbial flocs by tilapia in minimal discharge bioflocs technology ponds. Aquaculture, 264, 140-147 (2007).

Avnimelech, Y.: Biofloc Technology - A Practical Guide Book. $2^{\text {nd }}$ Edn., The World Aquaculture Society, Baton Rouge, Louisiana, United State (2012).

Avnimelech, Y., S. Mokady and G.L. Schoroder: Circulated ponds as efficient bioreactors for single cell protein production. Isr. J. Aquacult-Bamidgeh, 41, 58-66 (1989).
Ballester, E.L.C., P.C. Abreu, R.O. Cavalli, M. Emerenciano L. Abreu and W. Wasielesky: Effect of practical diets with different protein levels on the performance of Farfantepenaeus paulensis juveniles nursed in a zero exchange suspended microbial flocs intensive system. Aqua. Nutr., 16, 163-172 (2010).

Brostow, W., H.E.H. Lobland, S. Pal and R.P. Singh: Polymeric flocculant for wastewater and industrial effluent treatment. J. Mater. Educ., 31, 157-166 (2009).

Burford, M.A., P.J. Thompson, R.P. Mclntosh, R.H. Bauman and D.C. Pearson: Nutrient and microbial dynamics in high-intensity, zeroexchange shrimp ponds in Belize. Aquaculture, 219, 393-411 (2003).

Burford, M.A., P.J. Thompson, R.P. McIntosh, R.H. Bauman and D.C. Pearson: The contribution of flocculated material to shrimp (Litopenaeus vannamei) nutrition in a high intensity, zeroexchange system. Aquaculture, 232, 525-537 (2004).

Chen, M. and L.P. Zhao: Biodiversity of bacterial isolates on three different media from coking wastewater treatment system. Acta. Microbiol. Sin., 43, 367-371 (2003).

Choo, H.X., C. Marlowe and A. Caipang: Biofloc technology (BFT) and its application towards improved production in freshwater tilapia culture. Int. J. Bioflux Soc., 8, 362-366 (2015).

Chui, Y., W. Yuan and J. Cheng: Understanding pH and ionic strength effects on aluminum sulfate-induced microalgae flocculation. Appl. Biochem. Biotechnol., 173, 1692-1702 (2014).

Cosa, S., L.V. Mabinya, A.O. Olaniran, O.O. Okoh and A.I. Okoh: Bioflocculant production by Virgibacillus sp. rob isolated from the bottom sediment of Algoa Bay in the Eastern Cape, South Africa. Molecules, 16, 2431-2442 (2011).

Crab, R., T. Defoirdt, P. Bossier and W. Verstraete: Biofloc technology in aquaculture: Beneficial effects and future challenges. Aquaculture, 356-357, 351-356 (2012).

Dauda, A.B., N. Romano, M. Ebrahimi, J.C. Teh, A. Ajadi, C.M. Chong, M. Karim, I Natrah and M.S. Kamarudin: Influence of carbon/nitrogen ratios on biofloc production and biochemical composition and 
subsequent effects on the growth, physiological status and disease resistacne of African catfish (Clarias gariepinus) cultured in glycerol-based biofloc systems. Aquaculture, 483, 120-130 (2018).

FAO (Food and Agriculture Organization of the United Nation): SOFIAThe State of World Fisheries and Aquaculture [online]. Available from: http://www.fao.org/docrep/013/i1820e/i1820e00.htm. (2010).

Gao, J., H.Y. Bao, M.X. Xin, Y.X. Liu, Q. Li and Y.F. Zhang: Characterization of a bioflocculant from a newly isolated Vagococcus sp. W31. J. Zhejiang Univ. Sci. B., 7, 186-192 (2006).

Jang, G.I., C.Y. Hwang and B.C. Cho: Nitratireductor aquimarinus sp. nov., isolated from a culture of the diatom Skeletonema costatum, and emended description of the genus Nitratireductor. Int. J. Syst. Evol. Microbiol., 61, 2676-2681 (2011)

Hargreaves, J.A.: Photosynthetic suspended-growth system in aquaculture. J. Aquacult. Eng., 34, 334-363 (2006).

Hargreaves, J.A.: Biofloc production systems for aquaculture. J. South. RegionalAquacult. Centre (SRAC). 4503 (2013).

Kasan, N.A., S.M. Said, N.A. Ghazali, N.F.C. Hashim, Z. Ibrahim and N.M. Amin: Application of Biofloc in Aquaculture: An evaluation of flocculating activity of selected bacteria from biofloc. Beneficial microorganisms in agriculture, aquaculture and other areas (Ed.: M.T. Liong). Springer International Publishing Switzerland, Switzerland, pp 165-182 (2015).

Kumar, C.G., H.S. Joo, J.W. Choi, Y.M. Koo and C.S. Chang: Purification and characterization of an extracellular polysaccharide from haloalkalophilic Bacillus sp. I-450. Enzyme Microb. Technol., 34, 673-681 (2004).

Kurane, R., K. Hatamochi, T. Kiyohara, M. Hirao and Y. Taniguchi: Production of a bioflocculant by Rhodococcus erythropolis S-1 grown on alcohols. J. Biosci. Biotech. Bioch., 58, 428-429 (1994).

Labbé, N., S. Parent and R. Villemur: Nitratireductor aquibiodomus gen. nov., sp. nov., a novel a-proteobacterium from the marine denitrification system of the Montreal Biodome (Canada). Int. J. Syst. Evol. Microbiol., 54, 269-273 (2004).

Lara, G., D. Krummenauer, P.C. Abreu, L.H. Poersch and W. Wasielesky Jr.: The use of different aerators on Litopenaeus vannamei biofloc culture system: Effects on water quality, shrimp growth and biofloc composition. Aquacult. Int., 25, 147-162 (2016).

Li, W.W., W.Z. Zhou, Y.Z. Zhang, J. Wang and X.B. Zhu. Flocculation behavior and mechanism of an exopolysaccharide from the deepsea psychrophilic bacterium Pseudoalteromonas sp. SM9913. J. Bioresour. Technol., 99, 6893-6899 (2008).

Li, Z., S. Zhong, H.Y. Lei, Q. Yu and H.L. Li: Production of a novel bioflocculant by Bacillus licheniformis X14 and its application to low temperature drinking water treatment. J. Bioresour. Technol., 100, 3650-3656 (2009).

Liu, X., Y. Li, J. Li, L.Y. Cai, X.X. Li, J.R. Chen and S.X. Lyu: Isolation and characterisation of Bacillus spp. antagonistic to Vibrio parahaemolyticus for use as probiotics in aquaculture. World $\mathrm{J}$. Microbiol. Biotechnol., 31, 795-803 (2015).
Mikutta, R., U. Zang, J. Chorover, L. Haumaier and K. Kalbitz: Stabilization of extracellular polymeric substances (Bacillus subtilis) by adsorption to and coprecipitation with Al forms. Geochim. Cosmochim. Acta, 75, 3135-3154 (2011).

Ng, W.K., Y.C. Kim, N. Romano, C.B. Koh and S.Y. Yang: Effects of dietary probiotics on the growth and feeding efficiency of red hybrid tilapia, Oreochromis sp., and subsequent resistance to Streptococcus agalactiae. J. Appl. Aquacult., 26, 22-31 (2014).

Prakash, N.B., V. Sockan and P. Jayakaran: Waste water treatment by coagulation and flocculation. Int. J. Engin. Sci. Innovat. Technol., 3, 479-484 (2014)

Rakocy, J.E., D.S. Bailey, E.S. Thoman and R.C. Shultz: Intensive tank culture of tilapia with a suspended, bacterial based treatment process: New dimensions in farmed tilapia. In: Biomass Now Cultivation and Utilization (Eds.: R. Bolivar, G. Mair and K. Fitzsimmons). Proceedings of the Sixth International Symposium on Tilapia in Aquaculture, 322, 584-596 (2004).

Sam, S., F. Kucukasik, O. Yenigun, B. Nicolaus, E.B. Oner and M.A. Yukselen: Flocculating performances of exopolysaccharides produced by a halophilic bacterial strain cultivated on agroindustrial waste. Biores. Technol., 102, 1788-1794 (2011).

Simon, 0.: Micro-organisms as feed additives - Probiotics. Adv. Pork Prod., 16, 161-167 (2005).

Sorokulova, I.: Modern status and perspectives of Bacillus bacteria as probiotics. J. Probiotic Hlth., 1, 1-5 (2013).

Touraki, M., G. Karamanlidou, P. Karavida and K. Chrysi: Evaluation of the probiotics Bacillus subtilis and Lactobacillus plantarum bioencapsulated in Artemia nauplii against vibriosis in European sea bass larvae (Dicentrarchus labrax, L.). World J. Microbiol. Biotechnol., 28, 2425-2433 (2012).

Vijayalakshmi, S.P. and A.M. Raichur: Bioflocculation of high-ash Indian coals using Paenibacillus polymyxa. Int. J. Miner. Process, 67, 199-210 (2002).

Wang, Z., K.X. Wang, Y.M. Xie and Y.L. Yao: Bioflocculant-producing microorganisms. Acta Microbiol. Sin., 35, 121-129 (1995).

Wu, J. and H.F. Ye: Characterization and flocculating properties of an extracellular biopolymer produced from a Bacillus subtillis DYU1 isolate. Process Biochem., 42, 1114-1123 (2007).

Xu, W.J. and L.Q. Pan: Enhancement of immune response and antioxidant status of Litopenaeus vannamei juvenile in bioflocbased culture tanks manipulating high $\mathrm{C} / \mathrm{N}$ ratio of feed input. Aquaculture, 412-413, 117-124 (2013)

Yang, X.P., S.M. Wang, D.W. Zhang and I.X. Zhou: Isolation and nitrogen removal characteristic of an aerobic heterotrophic nitrifyingdenitrifying bacterium, Bacillus subtilis A1. Bioresour. Technol., 120, 854-862 (2011).

Zaki, S., S. Farag, G.A. Elreesh, M. Elkady, M. Nosier and D. Abd El Haleeml: Characterization of bioflocculants produced by bacteria isolated from crude petroleum oil. Int. J. Environ. Sci. Technol., 8, 831-840 (2011).

Zhang, C.L., Y.N. Cui and Y. Wang: Bioflocculant produced from bacteria for decolorization, $\mathrm{Cr}$ removal and swine wastewater application. Sustain Environ. Res., 22, 129-134 (2012). 